\title{
Multiple basal cell carcinomas arising within a nevus sebaceous
}

\section{Mnogie raki podstawnokomórkowe na podłożu znamienia łojowego}

\author{
Murat Ozturk', Ecem Bulut Okut², Zehra Akman Ilik \\ 'Health Sciences Universty, Van Training and Research Hospital, Department of Dermatology, Van, Turkey \\ 2Department of Dermatology, Tinaztepe University, Galen Hospital, Izmir, Turkey \\ ${ }^{3}$ Department of Pathology, Health Sciences Universty, Van Training and Research Hospital, Van, Turkey \\ Dermatol Rev/Przegl Dermatol 2020, 107, 396-399 \\ DOI: https://doi.org/I 0.5 I /4/dr.2020.99884
}

Nevus sebaceous (NS) is a benign hair follicle neoplasm seen approximately $1.3 \%$ of the population, typically affecting the scalp, neck or face. NS presents as a yellowish patch or plaque, but may develop papillomatous appearance especially after puberty. Basal cell carcinoma (BCC) is a rare result of NS. However it is the most common malignant neoplasm in NS. However, in general, the most common neoplasm is trichoblastoma [1-3].

A 27-year-old male patient was admitted to the outpatient clinic with complaint of black swellings on his scalp. It was learned that nevus was congenital and the swellings developed for approximately 2 years. Dermatological examination revealed 3 pieces greyish black papules between $2 \mathrm{~mm}$ and $1 \mathrm{~cm}$ in size on surface of a $6 \mathrm{~cm}^{2} \mathrm{NS}$ (fig. 1). In the dermoscopic examination of the lesion, branched and linear veins and bluish structureless areas including gray-white streak-like structures (lower left); bluish-white structureless area adjacent grayish papillomatous structure (middle) and gray-blue ovoid nests with thin branched veins and maple-like structures (upper right) were observed (fig. 2). On histopathological examination, tumor islets consisted of pigmented basaloid cells were observed. Increased staining was observed in neoplastic cells with $\mathrm{Ki}-67$ proliferation index, BER-EP4 and P53 (fig. 3). As a result of total excision of the lesion, with histopathologic and immunhistochemical findings, three BCC-compatible tumors and NS were observed. Surgical margins of tumors were intact. Evaluation of margins was done by vertical sectioning. Multiple BCCs arising on NS are extremely rare and we present this rare case with clinical histopathological and immunohistochemical features.

Nevus sebaceous is a rare congenital abnormality that can cause cosmetic deformation, alopecia or malignant transformation. If it is associated with syndromic features such as central nervous system
Znamię łojowe (nevus sebaceous - NS) jest łagodną zmianą nowotworową wywodzącą się z mieszka włosowego. Występuje u 1,3\% populacji, zazwyczaj na owłosionej skórze głowy, w obrębie twarzy lub szyi. Ma postać żółtawej plamki lub blaszki, ale szczególnie po okresie dojrzewania może stać się zmianą brodawkującą. Rzadkim następstwem NS jest rak podstawnokomórkowy (basal cell carcinoma - BCC). Jest to najczęstszy nowotwór złośliwy rozwijający się na podłożu NS, natomiast najczęstszym nowotworem skóry wywodzącym się z NS jest trichoblastoma [1-3].

Mężczyzna 27-letni zgłosił się do poradni z powodu czarnych, obrzękowych zmian umiejscowionych na owłosionej skórze głowy. Ustalono, że znamię ma charakter wrodzony, a obrzęk utrzymuje się od ok. 2 lat. W badaniu dermatologicznym stwierdzono obecność trzech szarawo-czarnych grudek o wielkości od $2 \mathrm{~mm}$ do $1 \mathrm{~cm}$, umiejscowionych na NS zajmującym powierzchnię $6 \mathrm{~cm}^{2}$ (ryc. 1). W obrazie dermoskopowym zmiany wykazano żyły o przebiegu rozgałęzionym i prostym oraz niebieskawe obszary bezstrukturalne, $\mathrm{w}$ tym szarobiałe struktury pasmowate (na dole po lewej); zaobserwowano również niebieskawo-biały obszar bezstrukturalny, przylegającą szarawą strukturę o charakterze brodawkowatym (w środku) oraz szaroniebieskie owalne gniazda z cienkimi, rozgałęzionymi naczyniami żylnymi i strukturami o wzorcu przypominającym liść klonu (u góry po prawej) (ryc. 2). W badaniu histopatologicznym stwierdzono obecność wysepek nowotworowych złożonych z barwnikowych komórek warstwy podstawnej naskórka. Zaobserwowano wzmożone wybarwienie w komórkach nowotworowych ze wskaźnikiem proliferacji Ki-67, BER-EP4 i P53 (ryc. 3). Po całkowitym wycięciu zmiany i uzyskaniu wyników badań histopatologicznych i immunohistochemicznych potwierdzono obecność trzech guzów o cechach odpowiadających BCC oraz NS. Zmiany usunięto z marginesem skóry zdrowej. Ocenę marginesów przeprowadzono na podstawie skrojeń wertykalnych. Mnogie występowanie BCC na podłożu NS 


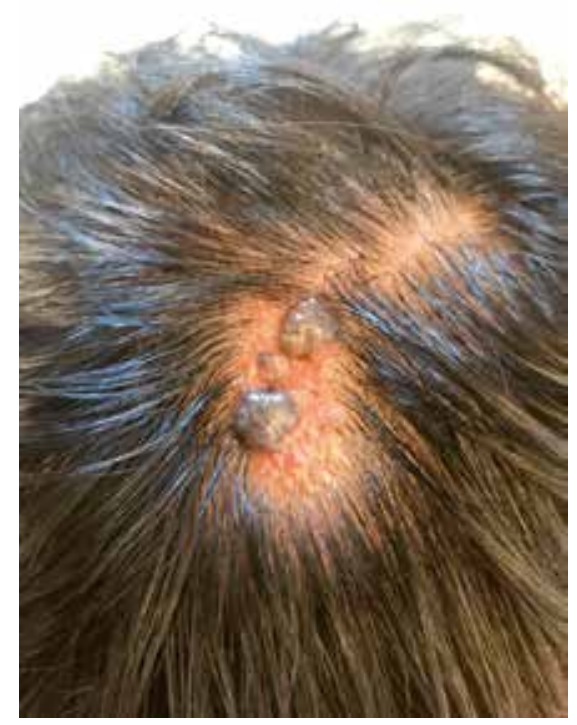

Figure I. Three greyish black papules between $2 \mathrm{~mm}$ and I $\mathrm{cm}$ in size on surface of nevus sebaceous

Rycina I. Trzy szarawo-czarne grudki o wielkości od $2 \mathrm{~mm}$ do I cm na powierzchni znamienia łojowego
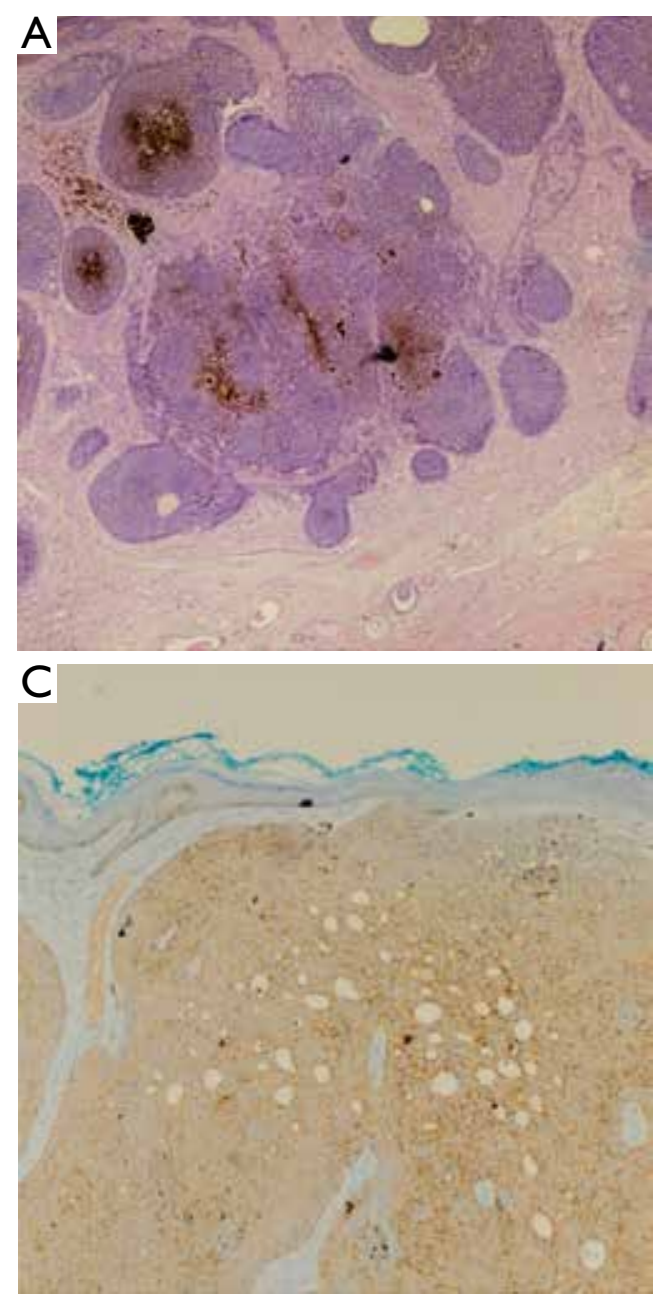

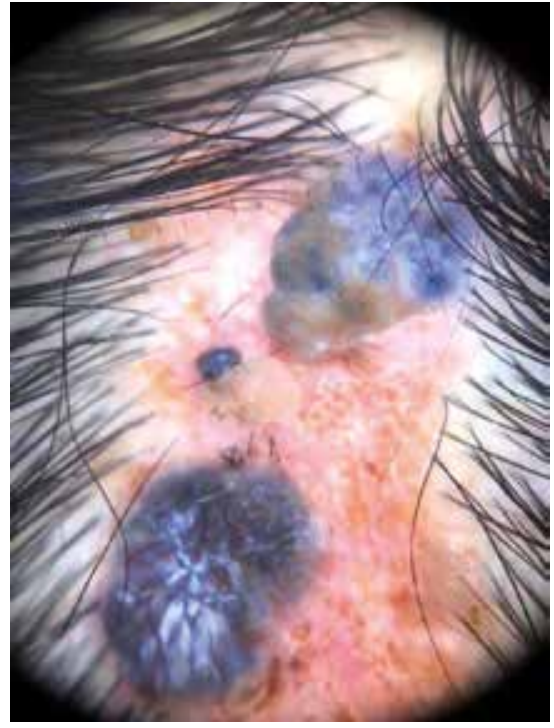

Figure 2. Dermoscopy of the lesions

Rycina 2. Obraz dermoskopowy zmian
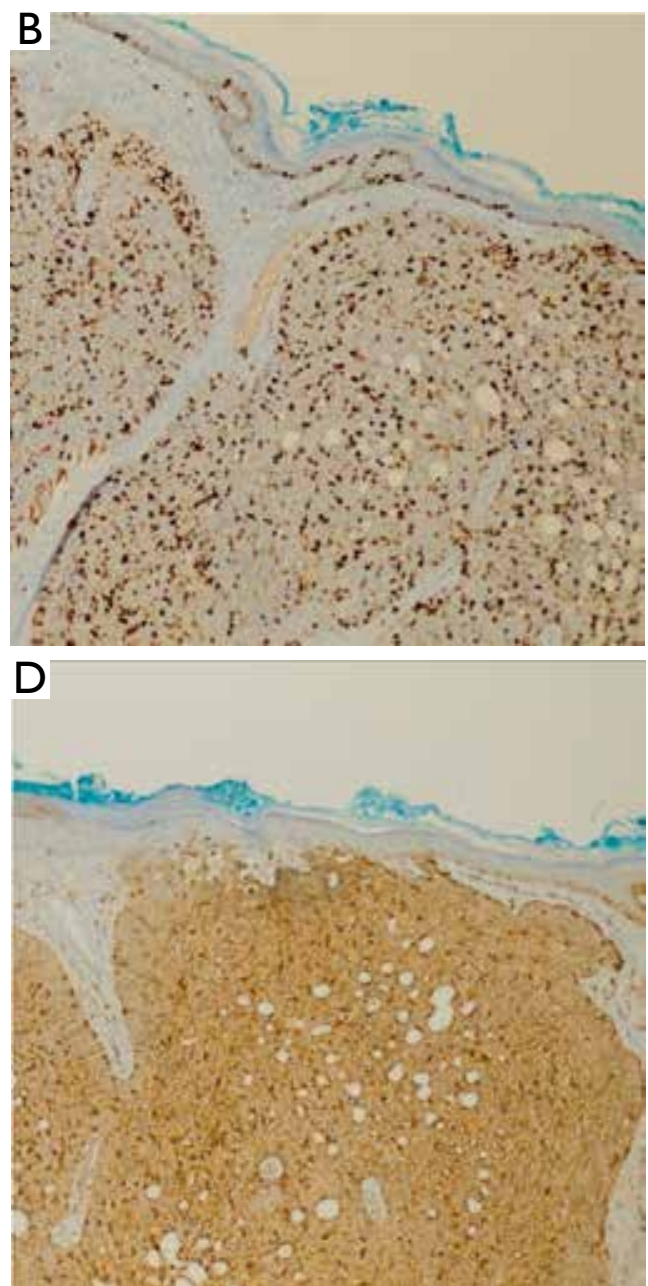

Figure 3. A - Histopathology of lesion (H\&E, 400X), B - BER-EP4 staining (I00×), C - P53 staining (I00X), D - Ki-67 staining (I00X) Rycina 3. A - Obraz histopatologiczny zmiany (barwienie H + E, 400×), B - barwienie BER-EP4 (I00×), C - barwienie P53 (I00X), D - barwienie Ki-67 (I00X) 
abnormalities, mental retardation, oculocardiac defects or skeletal abnormalities, this is called Schimmelpenning-Feuerstein-Mims syndrome. In adolescence, hormonal changes cause proliferation and hyperplasia of the lesion and cause more verrucous appearance which can be quite large. Later in life, the lesions may develop benign or malignant appendiageal tumors [1, 3-5]. It has been suggested that the lifetime risk for the malignant change of $\mathrm{SN}$ ranges between $5 \%$ and $22 \%$. There has been a lot of discussion about the true incidence of BCC that occurs in NS. An 18 -year review suggested the incidence to be around $0.8 \%$ (651 excised lesions) [1].

Nevus sebaceous is the most common adnexal tumor and is most commonly classified as a benign congenital hair follicle tumor located on the scalp and also seen on the face and neck. A secondary tumor originating from NS can be transformed into follicular, sebaceous, apocrine and eccrine cells. This fact shows the pluripotency of the nevus sebaceous. BCC is a rare result of sebaceous nevus. More recently, the most common tumor originating from NS has been found to be trichoblastoma instead of BCC, and BCC and other malignancies arising NS are relatively rare compared to other benign tumors [2, 3, 4,6]. Dilek et al. and Amin et al. reported a case of BCC secondary to NS [1,7]. However the reported BCC cases on NS are solitary and to the best of our knowledge our case is first report of multiple BCCs arising on NS.

While other studies advocated prophylactic excision of NS prior to the onset of the rapid growth phase (early puberty), some suggested that NS could be monitored for clinical changes and a biopsy or excision could be performed if such changes occur [8]. Rosen et al. suggested that all NS should be excised primarily for the risk of malignant transformation and secondary for cosmetic appearance. They reported that young age and uniform appearance of the lesion are not reliable criteria for making sure that a lesion is indeed benign [4].

Simultaneous tumor formation from a NS is not uncommon, but the number of tumors is usually less than three. The incidence of more than three multiple tumors is very rare [3]. In our case three BCC compatible lesions were observed. We present this case because multiple BCCs arising on NS is a rare condition.

\section{ACKNOWLEDGMENTS}

This case was presented as a poster presentation in IDEA Congress 2019.

\section{CONFLICT OF INTEREST}

The authors declare no conflict of interest. jest niezwykle rzadkim zjawiskiem. Przedstawiamy taki przypadek wraz z opisem cech klinicznych, histopatologicznych i immunohistochemicznych.

Znamię łojowe jest rzadko występującą wrodzoną zmianą skórną, która może powodować defekt kosmetyczny, utratę włosów lub ulegać zezłośliwieniu. W przypadku NS współistniejących z innymi objawami, takimi jak nieprawidłowości w obrębie ośrodkowego układu nerwowego, opóźnienie umysłowe, wady narządu wzroku i serca lub układu szkieletowego, rozpoznawany jest zespół Schimmelpenninga-Feuersteina-Mimsa. W okresie dojrzewania za sprawą zmian hormonalnych dochodzi do proliferacji i przerostu w obrębie zmiany, która staje się brodawkująca i może zajmować stosunkowo dużą powierzchnię. W późniejszym okresie życia ze zmian mogą się rozwijać łagodne lub złośliwe nowotwory przydatków [1, 3-5]. Wskazuje się, że w czasie całego życia ryzyko złośliwej transformacji NS wynosi od 5\% do $22 \%$. Rzeczywista częstość występowania BCC na podłożu NS jest przedmiotem dyskusji. W przeglądzie piśmiennictwa obejmującym 18 lat określono, że wynosi ona $0,8 \%$ (651 wyciętych zmian skórnych) [1].

Znamię łojowe to najbardziej rozpowszechniony guz przydatków, który jest zazwyczaj klasyfikowane jako łagodny, wrodzony guz wywodzący się z mieszków włosowych, umiejscowiony na owłosionej skórze głowy, twarzy lub szyi. Guz wtórny rozwijający się na podłożu NS może być skutkiem różnicowania w kierunku komórek mieszkowych, łojowych, apokrynowych i ekrynowych. Wskazuje to na pluripotencjalność NS. Rzadkim skutkiem NS jest BCC. Ostatnio stwierdzono, że najczęstszym nowotworem wywodzącym się z NS jest nie BCC, ale trichoblastoma. Zarówno BCC, jak i inne nowotwory złośliwe rozwijające się na podłożu NS występują stosunkowo rzadko $\mathrm{w}$ porównaniu $\mathrm{z}$ innymi nowotworami łagodnymi [2, 3, 4, 6]. Przypadek BCC wywodzącego się z NS opisano w pracach Dilek i wsp. oraz Amina i wsp. $[1,7]$. Należy zaznaczyć, że w dostępnym piśmiennictwie można znaleźć jedynie opisy występowania pojedynczych BCC na podłożu NS. Według naszej najlepszej wiedzy przedstawiony przypadek jest pierwszym doniesieniem dotyczącym mnogich BCC wywodzących się z NC.

Niektórzy badacze rekomendują profilaktyczne wycięcie NS przed rozpoczęciem fazy szybkiego wzrostu (tj. wczesnego okresu dojrzewania), natomiast w innych badaniach zaleca się monitorowanie NS w kierunku ewentualnych zmian klinicznych oraz wykonanie biopsji lub wycięcie NS w razie ich wystąpienia [8]. Rosen i wsp. wskazują na konieczność wykonywania zabiegu pierwotnego wycięcia we wszystkich przypadkach NS, głównie z uwagi na ryzyko złośliwej transformacji oraz wtórnie ze względów kosmetycznych. Badacze podkreślają, że młody wiek i jednolity wygląd zmiany nie stanowią wiarygodnych kryteriów determinujących jej lagodny charakter [4]. 
Jednoczesny rozwój guza na podłożu NS nie jest niezwykłym zjawiskiem, choć zazwyczaj liczba guzów jest mniejsza niż trzy. Występowanie więcej niż trzech guzów jest bardzo rzadkie [3]. W przedstawionym przypadku zaobserwowano trzy zmiany o obrazie odpowiadającym BCC. Przypadek został opisany ze względu na rzadkość mnogiego występowania BCC na podłożu NS.

\section{PODZIĘKOWANIA}

Przypadek został przedstawiony w ramach sesji plakatowej podczas Kongresu IDEA 2019.

\section{KONFLIKT INTERESÓW}

Autorzy nie zgłaszają konfliktu interesów.

\section{References}

\section{Piśmiennictwo}

1. Amin K., Orkar S.: Basal cell carcinoma arising in a sebaceous naevus. J Surg Case Rep 2015, 2015 , rjv046.

2. Segars K., Gopman J.M., Elston J.B., Harrington M.A.: Nevus Sebaceus of Jadassohn. Eplasty 2015, 15, ic38.

3. Namiki T., Miura K., Ueno M., Arima Y., Nishizawa A., Yokozeki H.: Four different tumors arising in a nevus sebaceous. Case Rep Dermatol 2016, 8, 75-79.

4. Rosen H., Schmidt B., Lam H.P., Meara J.G., Labow B.I.: Management of nevus sebaceous and the risk of basal cell carcinoma: an 18-year review. Pediatr Dermatol 2009, 26, 676-681.

5. Edgar N., Schuering R.A., Esguerra D., Miller R.A., van der Kooi K.: Primary cutaneous apocrine carcinoma arising within a nevus sebaceus. Cutis 2018, 102, 291-294.

6. Baykal C., Buyukbabani N., Yazganoglu K.D., Saglik E.: Tumors associated with nevus sebaceous. J Dtsch Dermatol Ges 2006, 4, 28-31.

7. Dilek N., Bedir R., Yüksel D., Ataseven A.: A case of basal cell carcinoma secondary to nevus sebaceous. Int J Case Rep Images 2014, 5, 277-280.

8. Barkham M.C., White N., Brundler M.A., Richard B., Moss C.: Should naevus sebaceus be excised prophylactically? A clinical audit. J Plast Reconstr Aesthet Surg 2007, 60, 1269-1270.

Received: 9.07.2020

Accepted: 31.08 .2020

Otrzymano: 9.07.2020 r.

Zaakceptowano: 31.08 .2020 r.

How to cite this article

Ozturk M., Okut E.B., Ilik Z.A.: Multiple basal cell carcinomas arising within a nevus sebaceous. Dermatol Rev/Przegl Dermatol 2020, 107, 396-399. DOI: https://doi.org/10.5114/dr.2020.99884. 